\title{
Doses of organic residues in soil mulch influence productivity and profitability of Peruvian carrot
}

\author{
Efecto de la dosis del acolchado de residuos orgánicos al suelo \\ en la productividad y la rentabilidad de la zanahoria peruana
Diego Menani Heid ${ }^{1}$, Néstor Antonio Heredia Zárate ${ }^{1}$, Elissandra Pacito Torales ${ }^{1}$, Lais de Lima Luqui ${ }^{1}$, Sidnei Azevedo de Souza ${ }^{1}$, Marianne Sales Abrão ${ }^{1}$

\begin{abstract}
Organic residue addition to soil is a recommended practice for arracacia production. This study was aimed at analyzing the agroeconomic productivity of arracacia cultivated with different doses $\left(0,5,10,15\right.$, and $\left.20 \mathrm{Mg} \mathrm{ha}^{-1}\right)$ and residue types in broiler manure (sawdust and rice hulls). From the arrangement in a $5 \times 2$ factorial scheme, ten treatments resulted, in a randomized complete block design with four replications. The highest leaf mass production was obtained with $11.2 \mathrm{Mg} \mathrm{ha}^{-1}$ of broiler manure. The use of broiler manure containing sawdust at $16 \mathrm{Mg} \mathrm{ha}^{-1}$ resulted in the highest shoot and root productivities. The maximum numbers of shoots were $649,500 \mathrm{ha}^{-1}$ and $651,560 \mathrm{ha}^{-1}$, with $12.48 \mathrm{Mg} \mathrm{ha}^{-1}$ and $9.20 \mathrm{Mg} \mathrm{ha}^{-1}$ of broiler manure containing sawdust and rice hulls, respectively. The maximum number of marketable roots was obtained by using $11.77 \mathrm{Mg} \mathrm{ha}^{-1}$ and $12.21 \mathrm{Mg} \mathrm{ha}^{-1}$ of broiler manure containing sawdust and rice hulls, respectively. The costs per hectare varied by $\mathrm{R} \$ 3,233.55$ between the lowest and highest costs. It was concluded that the highest productivity of marketable arracacia roots was obtained with $16 \mathrm{Mg} \mathrm{ha}^{-1}$ of broiler manure containing sawdust. The highest gross and net incomes were obtained with $15 \mathrm{Mg} \mathrm{ha}^{-1}$ of broiler manure containing sawdust.
\end{abstract}

Key-words: Organic residue, mulching, production, arracacha.

\section{RESUMEN}

El acolchado de residuos orgánicos al suelo es una práctica recomendada para la producción de arracacha. Este estudio tuvo como objetivo analizar la productividad agroeconómica de un cultivo de arracacha en suelos cubiertos con diferentes dosis $(0$, 5, 10, 15 y $20 \mathrm{th} \mathrm{h}^{-1}$ ) y tipos de residuos de camas avícolas. (Aserrín de madera y cáscaras de arroz). El diseño experimental fue un factorial de $5 \times 2$, con diez tratamientos, en un diseño de bloques completos al azar con cuatro repeticiones. El tratamiento con 16 tha $\mathrm{a}^{-1}$ de cama de aves con aserrín obtuvo la mayor productividad de brotes y raíces. El número máximo de brotes fue de 649,500 ha $a^{-1}$ y 651,560 ha-1, con 12,48 tha-1 y 9,20 tha-l de cama de aves con aserrín y cáscaras de arroz, respectivamente.

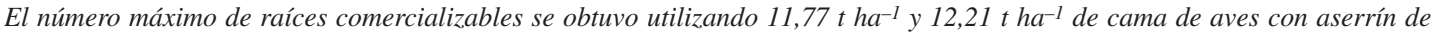
madera y cáscaras de arroz, respectivamente. Los costos por hectárea variaron en $R \$ 3.233,55$ entre el costo más bajo y el más alto. Los resultados sugieren que la mayor productividad de raices comercializables de zanahorias blancas se obtuvo con 16 tha-1 de cama de aves con aserrín y los mayores ingresos brutos y netos fueron con 15 tha ${ }^{-1}$ de cama de aves con aserrín de madera.

Palabras clave: Residuo orgánico, suelos cubiertos, producción, arracacha.

\section{Introduction}

In Brazil, the arracacia (Arracacia xanthorrhiza Bancroft), it is cultivated in small areas, with little input and family labor required, and considered a great alternative for small and medium producers (Madeira y Souza, 2004). It is a rustic plant, and can be planted throughout the year in certain localities in Brazil, with a vegetative cycle that varies based on the region of its cultivation, ranging from 8 to 12 months (Filgueira, 2008), and raising the possibility of partial harvests, enabling its maintenance in the soil until prices increase.

In the State of Mato Grosso do Sul (MS) in 2016, approximately 72 thousand $\mathrm{Mg}$ of arracacia roots were traded, of which only about $3,358 \mathrm{Mg}$ came from State producers, in the municipalities of Bandeirantes $(2,000 \mathrm{Mg})$ and Jaraguari $(1,350 \mathrm{Mg})$.

1 Federal University of Grande Dourados, Faculty of Agricultural Sciences, Dourados, MS, Brasil.

* Corresponding author: diegoheid@hotmail.com; nestorzarate@ufgd.edu.br; sidneiazevedo@ufgd.edu.br

Fecha de Recepción: 17 Abril, 2019.

Fecha de Aceptación: 21 Julio, 2019. 
The production of arracacia in MS has been boosted by the high economic value of its roots being marketed in boxes containing 10 kilos per values ranging from 140 to 160 R\$ (Chaves, 2016). The states of Paraná and Minas Gerais are the main producers, with an average yield of $8.8 \mathrm{Mg} \mathrm{ha}^{-1}$. Minas Gerais has more than 6,000 ha of cultivated land in more than 100 municipalities, and the southern region of this state is most productive, corresponding to approximately $70 \%$ of the production (Sediyama et al., 2008).

The arracacia (Arracacia xanthorrhiza Bancroft), whose roots are of economic interest and high nutritional quality (Carmo and Leonel, 2012), belongs to the family Apiaceae. Reserve roots of arracacia possess high nutritional value, and are rich in carbohydrates, minerals, and vitamins $\mathrm{A}$ and $\mathrm{C}$ (Pádua, 2010), in addition to containing starches free of anti-nutritional factors and low amylopectin levels, which are characteristics favoring high digestibility (Nunes et al., 2010).

Mulching is common in vegetable cultivation and involves the application of organic or inorganic material on the soil surface, thus improving its physical, chemical, and biological characteristics (Mangiori and Filho, 2015), especially in Cerrado soils, which are weathered, and contain low organic matter content. Among the organic residues used, broiler manure, composed of sawdust or rice hulls, is predominant. sawdust constitute the most accepted, recommended, and used residue, because of its high absorption and drying capacity, ease of handling, and good microbiological condition (Ávila et al., 2007). Rice hull is a material easily present in places where rice grain is processed; however, it has low absorption capacity, and comprises extremely small particles (Paula Júnior, 2014).
In arracacia cultivation, as in other cultures, each treatment or cultural technique presents specific demand for economic resources, with emphasis on the acquisition of inputs and labor, and it is essential to study profitability, and monitor costs, as with any economic activity (Melo et al., 2009). The costs involved in crop production can determine the success or failure of production by the farmer. Profitability is the ability of a particular investment to generate a return on its use (Tulsian, 2014).

Based on the aforementioned points, the aim of this study was to investigate the effects of broiler manure application on the yield and productivity of Arracacia xanthorrhiza.

\section{Material and Methods}

The study was developed in the area of the Faculty of Agricultural Sciences (FCA), Federal University of Grande Dourados (UFGD), Dourados, MS, between May 2014 and January 2015. The experimental area is located at $22^{\circ} 11^{\prime} 44^{\prime \prime} \mathrm{S}$ and $54^{\circ} 56^{\prime} 08^{\prime \prime} \mathrm{W}$ and altitude of $430 \mathrm{~m}$. The climate of the region, as per the Köppen-Geiger classification, is of the Am type (Alvares et al., 2013) with annual mean rainfall being greater than $1,500 \mathrm{~mm}$ and the driest month being less than $60 \mathrm{~mm}$. The precipitation and maximum and minimum temperatures registered in Dourados every ten days during the study are shown in Figure 1. The soil was classified as a Dystroferric Red Latosol (Santos et al., 2018).

The chemical attributes of the soil in the experimental area before planting and 250 days after planting (DAP) according to the treatments and chemical attributes of the semi-decomposed broiler manure used are presented in Table 1.

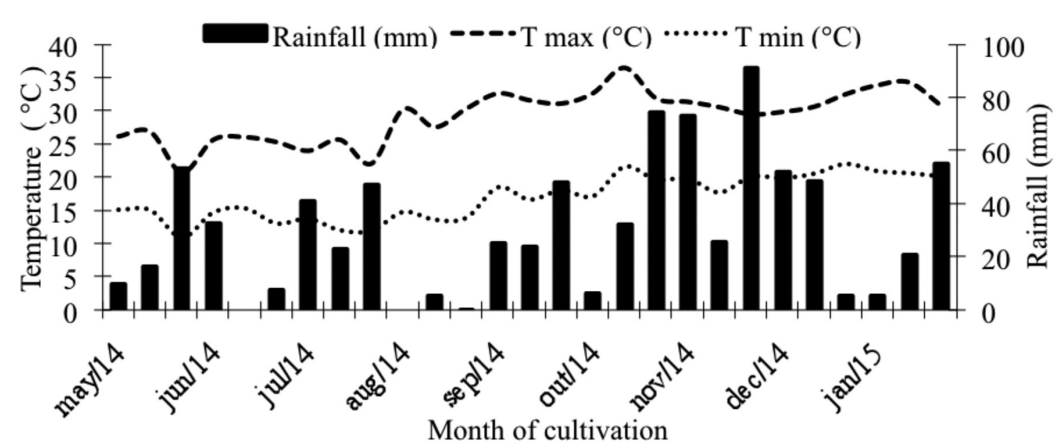

Figure 1. Maximum and minimum temperatures (average of ten-day periods) and total precipitation (every ten days) during the experiment, from May 2014 to January 2015. UFGD, Dourados, MS, 2014-2015. 


\section{Field phase}

The studied variables were dose $(0,5,10,15$, and $20 \mathrm{tha}^{-1}$ ) and type (sawdust and rice hulls) of broiler manure applied to cover the soil, arranged as a $5 \times 2$ factorial organized in an experimental randomized block design with ten treatments and four replicates. The plots had a plot area the $2.0 \mathrm{~m}^{2}$, containing three rows of plants spaced at $33.3 \mathrm{~cm}$ with spacing of $25 \mathrm{~cm}$ between plants, totaling a population of 79,200 plants per hectare.

Land preparation required two weeks before planting, with plowing, harrowing and subsequent seed bed lifting using rotary tillers.

For planting, shoots of the clone of Amarela de Carandaí arracacia, cultivated in Manhuaçu, MG, were used. The shoots were detached from the crowns one day before planting, selected, classified visually, and separated into groups of four sizes, with each group allocated to one repetition. On the day of planting, the shoots were prepared by cutting the aerial part, retaining approximately 2.0 $\mathrm{cm}$ of the petiole, and making a transverse section of the basal part. Planting was performed manually, leaving the shoot apices uncovered (Heredia Zárate et al., 2009), and after planting, broiler manure was immediately distributed over the surface in parcels corresponding to each dose.

Plants were irrigated using the sprinkler system, and from the initial phase until the time when plant height was $15-20 \mathrm{~cm}$, which was approximately 60 DAP, the plants were irrigated every two days; from then to $180 \mathrm{DAP}$, the plants were irrigated every three days, and later, until harvest, they were irrigated once a week. Weed control was performed using a hoe between seedbeds, and manually inside the seedbeds. In the experimental area, there was an incidence of aphid infestation (Hyadaphis foeniculi), and control was performed using Neem oil.

When the plants exhibited approximately $70 \%$ leaf senescence, which occurred at 250 DAP, the plants were harvested, and the fresh and dry masses (obtained after drying the material in a stove with forced air ventilation to constant mass at $65 \pm 2^{\circ} \mathrm{C}$ ) of marketable (mass over $25 \mathrm{~g}$ and no damaged) roots, leaves, shoots, and were crowns evaluated. The numbers of shoots and marketable roots were

Table 1. Chemical attributes of soil samples collected from the experimental area before planting (BP) and 250 days after planting (DAP) Amarela de Carandaí arracacia cultivated in soil covered with different doses and types of broiler manure. UFGD, Dourados, MS, 2014-2015.

\begin{tabular}{|c|c|c|c|c|c|c|c|c|c|c|c|}
\hline \multirow{3}{*}{ Soil attribute ${ }^{1}$} & \multirow{3}{*}{$\mathrm{BP}^{3}$} & \multicolumn{10}{|c|}{ Treatment (broiler manure coverage; $\left.\mathrm{t} \mathrm{ha}^{-1}\right)^{4}$} \\
\hline & & \multicolumn{5}{|c|}{ Rice hulls } & \multicolumn{5}{|c|}{ Sawdust } \\
\hline & & 0 & 5 & 10 & 15 & 20 & 0 & 5 & 10 & 15 & 20 \\
\hline $\mathrm{pH}$ in $\mathrm{CaCl}_{2}$ & 5.57 & 5.55 & 5.56 & 5.56 & 5.56 & 5.62 & 5.53 & 5.41 & 5.43 & 5.52 & 5.39 \\
\hline $\mathrm{pH}$ in water & 6.20 & 6.19 & 6.20 & 6.20 & 6.20 & 6.25 & 6.17 & 6.07 & 6.08 & 6.16 & 6.05 \\
\hline $\mathrm{P}\left(\mathrm{mg} \mathrm{dm}^{-3}\right)$ & 13.99 & 9.85 & 10.52 & 11.18 & 17.20 & 21.22 & 17.87 & 20.55 & 14.53 & 17.87 & 15.87 \\
\hline $\mathrm{K}\left(\mathrm{cmol}_{\mathrm{c}} \mathrm{dm}^{-3}\right)$ & 0.31 & 0.29 & 0.39 & 0.23 & 0.32 & 0.34 & 0.31 & 0.21 & 0.32 & 0.23 & 0.24 \\
\hline $\mathrm{Al}^{+3}\left(\mathrm{cmol}_{\mathrm{c}} \mathrm{dm}^{-3}\right)$ & 0.12 & 0.12 & 0.12 & 0.12 & 0.12 & 0.12 & 0.12 & 0.12 & 0.12 & 0.12 & 0.12 \\
\hline $\mathrm{Ca}\left(\mathrm{cmol}_{\mathrm{c}} \mathrm{dm}^{-3}\right)$ & 2.90 & 2.74 & 2.75 & 2.69 & 3.17 & 3.16 & 3.06 & 3.22 & 3.11 & 3.21 & 3.04 \\
\hline $\mathrm{Mg}\left(\mathrm{cmol}_{\mathrm{c}} \mathrm{dm}^{-3}\right)$ & 2.08 & 1.92 & 1.94 & 1.96 & 2.13 & 2.48 & 2.37 & 2.55 & 2.35 & 2.54 & 2.12 \\
\hline $\mathrm{H}+\mathrm{Al}\left(\mathrm{cmol}_{\mathrm{c}} \mathrm{dm}^{-3}\right)$ & 3.28 & 3.86 & 3.16 & 3.51 & 3.06 & 2.81 & 3.55 & 3.55 & 3.63 & 3.44 & 3.29 \\
\hline $\mathrm{SB}\left(\mathrm{cmol}_{\mathrm{c}} \mathrm{dm}^{-3}\right)$ & 5.29 & 4.96 & 5.08 & 4.89 & 5.62 & 5.98 & 5.74 & 5.98 & 5.78 & 5.98 & 5.41 \\
\hline CTC $\left(\mathrm{cmol}_{\mathrm{c}} \mathrm{dm}^{-3}\right)$ & 8.57 & 8.82 & 8.24 & 8.40 & 8.68 & 8.79 & 9.29 & 9.53 & 9.41 & 9.42 & 8.70 \\
\hline $\mathrm{V}(\%)$ & 61.73 & 56.20 & 61.69 & 58.18 & 64.77 & 68.03 & 61.78 & 62.77 & 61.45 & 63.50 & 62.13 \\
\hline \multicolumn{12}{|c|}{ Broiler manure attribute $^{2}$} \\
\hline Total humidity & $\begin{array}{c}\mathrm{Zn} \\
\left(\mathrm{mg} \mathrm{kg}^{-1}\right)\end{array}$ & $\begin{array}{c}\mathrm{Mn} \\
\left(\mathrm{mg} \mathrm{kg}^{-1}\right)\end{array}$ & $\begin{array}{c}\mathrm{Cu} \\
\left(\mathrm{mg} \mathrm{kg}^{-1}\right)\end{array}$ & $\begin{array}{c}\mathrm{Fe} \\
\left(\mathrm{g} \mathrm{kg}^{-1}\right)\end{array}$ & $\begin{array}{c}\mathrm{Ca} \\
\left(\mathrm{g} \mathrm{kg}^{-1}\right)\end{array}$ & $\begin{array}{c}\mathrm{Mg} \\
\left(\mathrm{g} \mathrm{kg}^{-1}\right)\end{array}$ & $\begin{array}{c}\mathrm{K} \\
\left(\mathrm{g} \mathrm{kg}^{-1}\right)\end{array}$ & & $\begin{array}{l}\mathrm{P} \\
\left.\mathrm{kg}^{-1}\right)\end{array}$ & $\begin{array}{l}\mathrm{N} \\
(\%)\end{array}$ & $\mathrm{C} / \mathrm{N}$ \\
\hline $21.75^{5}$ & 299.00 & 422.00 & 1.04 & 53.10 & 12.04 & 5.90 & 24.63 & & 61 & 10.80 & 10.02 \\
\hline $20.74^{6}$ & 414.00 & 871.00 & 6.05 & 33.70 & 19.29 & 8.50 & 16.80 & & .58 & 15.30 & 8.75 \\
\hline
\end{tabular}

${ }^{1}$ Analyses conducted at the FCA/UFGD Soil Laboratory; ${ }^{2}$ Analyses conducted in the laboratory of organic matter and residues of the UFV; ${ }^{3}$ Before planting; ${ }^{4}$ Treatment with broiler manure coverage (t ha ${ }^{-1}$ ); ${ }^{5}$ Rice hulls; ${ }^{6}$ Sawdust. 
counted, and additionally, the diameter and length of marketable roots were measured.

When significant differences were detected using an F-test productivity data were examined by regression analysis.

\section{Agroeconomic evaluation}

Production costs were calculated using the table of the cost of production of Amarela de Carandaí arracacia, presented by Heid et al. (2015). The cost of seedlings was calculated by considering the total number of seedlings required for field cultivation, after calculating the population, multiplied by the value of the seedlings, $R \$ 2.00 \mathrm{~kg}^{-1}$.

To determine the cost of labor, the number of men required per day to perform each job was multiplied by the remuneration for temporary labor in Dourados, MS at the time of the experiment (R\$ 45.00 day $^{-1}$ ).

The cost of machinery, tractors and irrigation pumps was calculated by recording the hours required to perform the job required for each operation, and converted to hour/machine per hectare, and multiplied by the value of the use of each machine.

To determine gross income, the production of the fresh mass of marketable roots was used, and the price was $\mathrm{R} \$ 6.00 \mathrm{~kg}^{-1}$, corresponding to $60 \%$ of the average value for commercialization in Ceasa of Campo Grande, MS, from November to December 2014, when market value was $\mathrm{R} \$ 10.00$ $\mathrm{kg}^{-1}$. Net income was calculated from gross income less the costs of production per hectare cultivated.

\section{Results and Discussion}

The fresh mass of arracacia leaves was significantly influenced by the fertilization rate of broiler manure applied to cover the soil, and exhibited quadratic growth (Figure 2), with a maximum value of $3.41 \mathrm{Mg} \mathrm{ha}^{-1}$ for the plants grown in soil covered with 11.2 $\mathrm{Mg} \mathrm{ha}^{-1}$ of broiler manure, for the two residue types used. When applied as a cover over soil, broiler manure increases water storage in the soil (Chen et al., 2014), helps in the gradual release of nutrients into the soil, and increases biological activity (Hoshino et al., 2016), resulting in an increase in fresh mass production. The decrease in plant productivity after reaching the maximum value was explained by Oliveira et al. (2009), who suggested that high levels of organic residues could

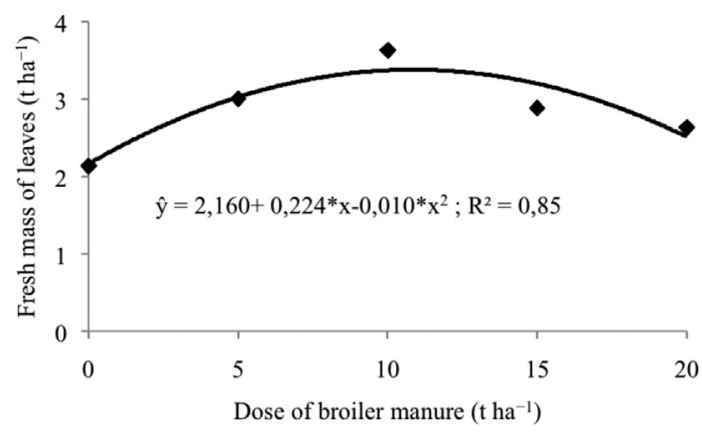

Figure 2. Fresh mass of leaves of arracacia grown in soil covered with different doses and types of broiler manure. UFGD, Dourados, MS, 2014-2015. * = significant at 5\% probability.

cause nutrient imbalance in the soil and consequent reduction in the development and final production of the crop. There was no significant difference regarding the types of residues used in the broiler manure, with an average of $2.84 \mathrm{Mg} \mathrm{ha}^{-1}$.

Fresh shoot masses (Figure 3) and marketable roots (Figure 4) were influenced by the interaction of the analyzed factors. The use of sawdust yielded the highest productivity of fresh shoot mass, generating a maximum value of $6.70 \mathrm{Mg} \mathrm{ha}^{-1}$ using $18.25 \mathrm{Mg}$ $\mathrm{ha}^{-1}$ of broiler manure, with an increase of $1.03 \mathrm{Mg}$ ha $^{-1}(15.40 \%)$, relative to rice hulls (Figure 3). Data for rice hulls did not adjust to the regression models, resulting in an average productivity of $5.67 \mathrm{Mg} \mathrm{ha}^{-1}$. Although broiler manure was applied to cover the soil, it probably induced changes in aeration and water retention capacity, which possibly increased the activity of microbial processes in the soil, in response to organic decomposition, which may have occurred as a function of the long vegetative cycle of the arracacia, favoring the growth and development of plant mass (Kiehl, 2010).

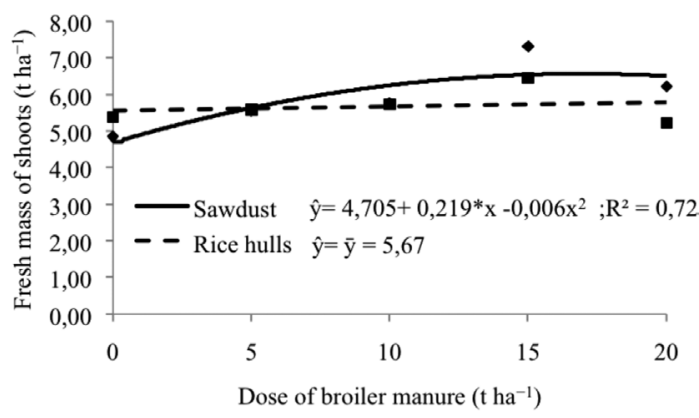

Figure 3. Fresh mass of shoots of arracacia grown in soil covered with different doses and types of broiler manure. UFGD, Dourados, MS, 2014-2015. * = significant at 5\% probability. 
The fresh and dry crown masses were not significantly influenced by the manure dose or residue type, exhibiting average productivities of $3.89 \mathrm{Mg} \mathrm{ha}^{-1}$ and $0.78 \mathrm{Mg} \mathrm{ha}^{-1}$, respectively. This finding was observed probably because the crowns were initially the preferred sinks until they reached maturity, when the roots became the preferred sinks.

The fresh masses of marketable roots were adjusted to the quadratic model for sawdust, and to the linear model for rice hulls. The maximum productivity of marketable roots $\left(5.75 \mathrm{Mg} \mathrm{ha}^{-1}\right)$, was obtained with sawdust $\left(16 \mathrm{Mg} \mathrm{ha}^{-1}\right)$, generating an increase of $1.42 \mathrm{Mg} \mathrm{ha}^{-1}$ (24.7\%), relative to rice hulls, which generated the maximum productivity (4.33 $\mathrm{Mg} \mathrm{ha}^{-1}$ ) when 20 tha $^{-1}$ of rice hulls was used (Figure 4). The best result obtained might be related to differences in nutrient contents in both residues (Table 1), because the broiler manure based on sawdust contained higher levels of zinc ( $\mathrm{Zn})$, manganese $(\mathrm{Mn})$, iron $(\mathrm{Fe})$, calcium $(\mathrm{Ca})$, magnesium $(\mathrm{Mg})$, and phosphorus $(\mathrm{P})$, which may have been more available throughout the plant cycle because of lower $\mathrm{C} / \mathrm{N}$ ratio. The results were consistent with the reports by Torales et al. (2014), who observed the elevation in $\mathrm{P}, \mathrm{K}$, and $\mathrm{Mg}$ levels in soil after broiler manure application for the production of commercial arracacia roots.

The observation that the highest productivity obtained in this study was lower than the national average, which is $9.3 \mathrm{t} \mathrm{ha}^{-1}$ (Madeira and Souza, 2004) and maximum productivity obtained in other experimental studies conducted in Dourados, including $14.0 \mathrm{Mg} \mathrm{ha}^{-1}$ obtained by Torales et al. (2010) and $22.08 \mathrm{Mg} \mathrm{ha}^{-1}$ obtained by Heid et al. (2015), but they are in agreement with Heid et al. (2019), that is, average productivity $\left(6.30 \mathrm{Mg} \mathrm{ha}^{-1}\right)$,

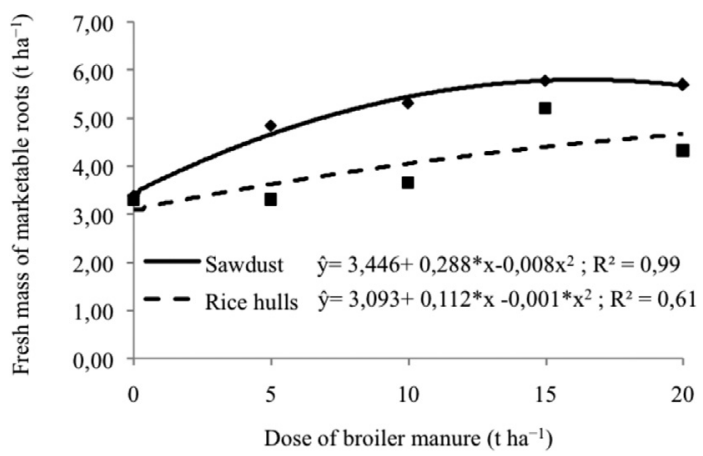

Figure 4. Fresh mass of marketable roots of arracacia grown in soil covered with different doses and types of broiler manure. UFGD, Dourados, MS, 2014-2015. * = significant at 5\% probability. a might be related to maximum temperatures above $32^{\circ} \mathrm{C}$ and an average of $26.5^{\circ} \mathrm{C}$ from September on wards (Figure 1), when the phase of extensive translocation of reserve photosynthates from the aerial parts to roots (Graciano et al., 2006) occurs in addition to the thickening and characterization of marketable roots until harvest.

In addition to high temperature, pest attack (Hyadaphis foeniculi) may have contributed to the reduction in the productivity of marketable roots of arracacia, since it could not be adequately controlled despite the use of Neem oil.

The dry masses of crown, shoots, and marketable roots were not significantly influenced by the analyzed factors, exhibiting averages of $0.78 \mathrm{Mg}$ $\mathrm{ha}^{-1}, 0.91 \mathrm{Mg} \mathrm{ha}^{-1}$, and $0.85 \mathrm{t} \mathrm{ha}^{-1}$, respectively. Although these characteristics of dry mass were not significant with use of broiler manure, there were productive increases for fresh mass. Similar results were observed by Torales et al. (2010), who attributed the high turgidity of the organs involved in the translocation and storage of photosynthates to the use of broiler manure, owing to high water retention by organic matter.

The highest dry leaf mass $\left(0.85 \mathrm{Mg} \mathrm{ha}^{-1}\right)$ was obtained from the plants grown in soil covered with broiler manure containing rice hulls, exceeding that obtained with sawdust $\left(0.60 \mathrm{Mg} \mathrm{ha}^{-1}\right)$ by 0.25 $\mathrm{Mg} \mathrm{ha}^{-1}$. The use of broiler manure containing rice hulls may have resulted in the low productivity of the preferred sinks (Figure 4), by possibly inducing reduced photosynthate translocation to them.

The numbers of shoots and marketable roots were significantly influenced by the interaction of the analyzed factors. The maximum numbers of shoots were 649,500 ha-1 and 651,560 ha-1, with the use of $12.48 \mathrm{Mg} \mathrm{ha}^{-1}$ and $9.20 \mathrm{Mg} \mathrm{ha}^{-1}$ of broiler manure based on sawdust and rice hulls, respectively (Figure 5).

The number of marketable roots was adjusted to the quadratic model for both types of broiler manure residues. The highest values $\left(134.93 \mathrm{ha}^{-1}\right.$ and $108.52 \mathrm{ha}^{-1}$ ) were obtained when $11.77 \mathrm{Mg} \mathrm{ha}^{-1}$ and $12.21 \mathrm{Mg} \mathrm{ha}^{-1}$ of broiler manure with sawdust and rice hulls, respectively, were used (Figure 6), with the first value exceeding the second by $19.57 \%$. Valadão et al. (2011) reported that production systems using broiler manure, either semi-decomposed or composted, tend to induce considerable changes in the physical and chemical attributes of soil, and consequently, increase crop productivity. 


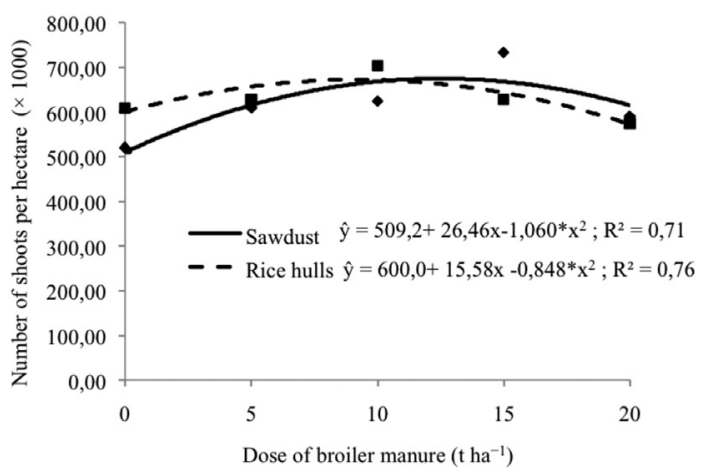

Figure 5. Number of shoots of arracacia grown in soil covered with different doses and types of broiler manure. UFGD, Dourados, MS, 2014-2015. * = significant at 5\% probability.

Therefore, covering of soil with broiler manure may have improved infiltration and water retention, and consequently improved the distribution of the arracacia root system.

The diameters of the marketable roots were significantly influenced by the interaction of the analyzed variables. Marketable root diameter was fitted to the linear model for both residue types (Figure 7). Maximum values ( $28.57 \mathrm{~mm}$ and 28.02 $\mathrm{mm}$ ) were obtained with $10.92 \mathrm{Mg} \mathrm{ha}^{-1}$ and 12.08 $\mathrm{Mg} \mathrm{ha}^{-1}$ of broiler manure with sawdust and rice hulls, respectively. The largest diameter and length of marketable roots differed from those reported by Heid et al. (2015), who obtained maximum values of length and diameter of $9.8 \mathrm{~cm}$ and $39.66 \mathrm{~mm}$, respectively, while studying the agroeconomic productivity of arracacia in response to broiler manure application to soil surface. This difference may have arisen because of the mode of residue application, since incorporated broiler manure

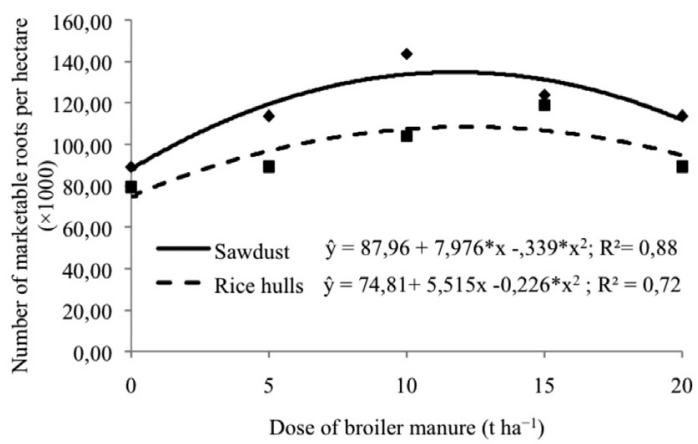

Figure 6. Number of marketable roots of arracacia grown in soil covered with different doses and types of broiler manure. UFGD, Dourados, MS, 2014-2015. * = significant at 5\% probability. application stimulates the activity of microorganisms, producing substances inducing the agglutination of soil particles, thus improving its structure (Kiehl, 2010), and enabling roots to grow in diameter and length.

The estimated costs to cultivate of Amarela de Carandaí arracacia in 1.0 ha of soil covered with broiler manure at different doses $(0,5,10,15$, and $20 \mathrm{Mg} \mathrm{ha}^{-1}$ ) and types (sawdust and rice hulls) varied by $R \$ 3.233,55$ between the lowest cost $(R \$$ $11,805.58)$, corresponding to cultivation in soil with out broiler manure application, and the highest cost ( $\mathrm{R} \$ 15,039.13)$, calculated for cultivation in soil with the application of $20 \mathrm{Mg} \mathrm{ha}^{-1}$ of broiler manure (Table 2).

The variable costs corresponded to the sum of the costs of input, labor, and machinery, representing $70.80 \%$ ( $\mathrm{R} \$ 8,357.62$ ) for cultivation in the soil without surface application of broiler manure, which had the lowest cost of production, and $73.53 \%$ (R\$ $11,057.62)$ for cultivation in the soil covered with $20 \mathrm{Mg} \mathrm{ha}^{-1}$ of broiler manure, which carried the highest production cost. Labor costs were related to seedling preparation, planting, distribution of broiler manure when necessary, irrigation, weeding, and harvesting, representing $33.92 \%$ ( $\mathrm{R} \$ 4,005.00)$ of the total cost of cultivation in soil without broiler manure addition for cover, and 32.61\% (R\$ 4,905.00) for cultivation in soil covered with $20.00 \mathrm{Mg} \mathrm{ha}^{-1}$ of broiler manure at 250 DAP. The differences in costs were related to broiler manure application in the respective treatments. Regarding labor, arracacia cultivation proves to be an important generator of jobs in the agricultural sector, since it creates considerable demand for labor to execute different cultivation practices (Heid et al., 2015).

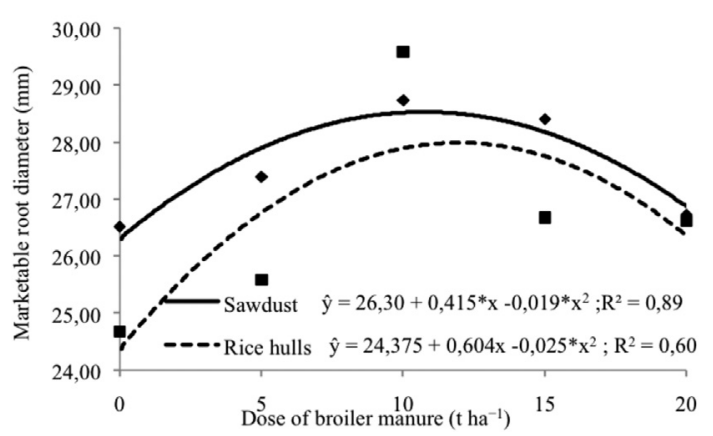

Figure 7. Diameter of marketable roots of arracacia grown in soil covered with different doses and types of broiler manure. UFGD, Dourados, MS, 2014-2015. * = significant at 5\% probability. 
Table 2. Production costs for Amarela de Carandaí arracacia cultivated in one hectare of soil covered with different doses of broiler manure. UFGD, Dourados, MS, 2014-2015.

\begin{tabular}{|c|c|c|c|c|c|c|c|c|c|c|}
\hline \multirow{2}{*}{$\frac{\text { Cost Components }}{\text { 1. Variable Costs }}$} & \multicolumn{2}{|c|}{ Without broiler manure } & \multicolumn{2}{|c|}{$5\left(\mathrm{t} \mathrm{ha}^{-1}\right)$} & \multicolumn{2}{|c|}{$10\left(\mathrm{t} \mathrm{ha}^{-1}\right)$} & \multicolumn{2}{|c|}{$15\left(\mathrm{t} \mathrm{ha}^{-1}\right)$} & \multicolumn{2}{|c|}{$20\left(\mathrm{t} \mathrm{ha}^{-1}\right)$} \\
\hline & Quantity & Cost $(\mathrm{R} \$)$ & Quantity & Cost $(\mathrm{R} \$)$ & Quantity & Cost $(\mathrm{R} \$)$ & Quantity & Cost $(\mathrm{R} \$)$ & Quantity & Cost $(\mathrm{R} \$)$ \\
\hline \multicolumn{11}{|c|}{ Input } \\
\hline Seedlings ${ }^{1}(\mathrm{~kg})$ & $1,237.10$ & $2,721.62$ & $1,237.10$ & $2,721.62$ & $1,237.10$ & $2,721.62$ & $1,237.10$ & $2,721.62$ & $1,237.10$ & $2,721.62$ \\
\hline Neem oil ${ }^{5}$ (liter) & 4.50 & 351.00 & 4.50 & 351.00 & 4.50 & 351.00 & 4.50 & 351.00 & 4.50 & 351.00 \\
\hline Broiler manure $^{2}$ & - & - & 5 & 450.00 & 10 & 900.00 & 15 & $1,350.00$ & 20 & $1,800.00$ \\
\hline \multicolumn{11}{|c|}{ Labor } \\
\hline Labor & $8.00 \mathrm{H} / \mathrm{D}$ & 360.00 & $8.00 \mathrm{H} / \mathrm{D}$ & 360.00 & $8.00 \mathrm{H} / \mathrm{D}$ & 360.00 & $8.00 \mathrm{H} / \mathrm{D}$ & 360.00 & $8.00 \mathrm{H} / \mathrm{D}$ & 360.00 \\
\hline Planting & $16.00 \mathrm{H} / \mathrm{D}$ & 720.00 & $16.00 \mathrm{H} / \mathrm{D}$ & 720.00 & $16.00 \mathrm{H} / \mathrm{D}$ & 720.00 & $16.00 \mathrm{H} / \mathrm{D}$ & 720.00 & $16.00 \mathrm{H} / \mathrm{D}$ & 720.00 \\
\hline CF of Distribution & - & - & $5.00 \mathrm{H} / \mathrm{D}$ & 225.00 & $10.00 \mathrm{H} / \mathrm{D}$ & 450.00 & $15.00 \mathrm{H} / \mathrm{D}$ & 675.00 & $20.00 \mathrm{H} / \mathrm{D}$ & 900.00 \\
\hline Irrigation & $10.00 \mathrm{H} / \mathrm{D}$ & 450.00 & $10.00 \mathrm{H} / \mathrm{D}$ & 450.00 & $10.00 \mathrm{H} / \mathrm{D}$ & 450.00 & $10.00 \mathrm{H} / \mathrm{D}$ & 450.00 & $10.00 \mathrm{H} / \mathrm{D}$ & 450.00 \\
\hline Neem oil application & $5.00 \mathrm{H} / \mathrm{D}$ & 225.00 & $5.00 \mathrm{H} / \mathrm{D}$ & 225.00 & $5.00 \mathrm{H} / \mathrm{D}$ & 225.00 & $5.00 \mathrm{H} / \mathrm{D}$ & 225.00 & $5.00 \mathrm{H} / \mathrm{D}$ & 225.00 \\
\hline Weeding & $20.00 \mathrm{H} / \mathrm{D}$ & 900.00 & $20.00 \mathrm{H} / \mathrm{D}$ & 900.00 & $20.00 \mathrm{H} / \mathrm{D}$ & 900.00 & $20.00 \mathrm{H} / \mathrm{D}$ & 900.00 & $20.00 \mathrm{H} / \mathrm{D}$ & 900.00 \\
\hline Harvest & $30.00 \mathrm{H} / \mathrm{D}$ & $1,350.00$ & $30.00 \mathrm{H} / \mathrm{D}$ & $1,350.00$ & $30.00 \mathrm{H} / \mathrm{D}$ & $1,350.00$ & $30.00 \mathrm{H} / \mathrm{D}$ & $1,350.00$ & $30.00 \mathrm{H} / \mathrm{D}$ & $1,350.00$ \\
\hline \multicolumn{11}{|c|}{ Machinery } \\
\hline Irrigation pump & $80.00 \mathrm{~h}$ & 800.00 & $80.00 \mathrm{~h}$ & 800.00 & $80.00 \mathrm{~h}$ & 800.00 & $80.00 \mathrm{~h}$ & 800.00 & $80.00 \mathrm{~h}$ & 800.00 \\
\hline Tractor & $8.00 \mathrm{~h}$ & 480.00 & $8.00 \mathrm{~h}$ & 480.00 & $8.00 \mathrm{~h}$ & 480.00 & $8.00 \mathrm{~h}$ & 480.00 & $8.00 \mathrm{~h}$ & 480.00 \\
\hline Subtotal 1() & & $8,357.62$ & & $9,032.62$ & & $9,707.62$ & & $10,382.62$ & & $11,057.62$ \\
\hline \multicolumn{11}{|c|}{ 2. Fixed Costs } \\
\hline Improvement & 250 days & 375.00 & 250 days & 375.00 & 250 days & 375.00 & 250 days & 375.00 & 250 days & 375.00 \\
\hline Remuneration of land ${ }^{3}$ & $1.00 \mathrm{ha}$ & $1,350.00$ & $1.00 \mathrm{ha}$ & $1,350.00$ & 1.00 ha & $1,350.00$ & $1.00 \mathrm{ha}$ & $1,350.00$ & $1.00 \mathrm{ha}$ & 1.350 .00 \\
\hline Subtotal $2(\mathrm{R} \$)$ & & $1,725.00$ & & $1,725.00$ & & $1,725.00$ & & $1,725.00$ & & $1,725.00$ \\
\hline \multicolumn{11}{|c|}{ 3. Other costs (ST1) } \\
\hline Contingency (10\%) & & 835.76 & & 903.26 & - & 970.76 & & 1038.26 & & 1105.76 \\
\hline Administration (5\%) & & 417.88 & & 451.63 & & 485.38 & & 519.13 & & 552.88 \\
\hline Subtotal 3 & - & $1,253.64$ & - & $1,354.89$ & - & $1,456.14$ & - & $1,557.39$ & - & $1,658.64$ \\
\hline TOTAL & & $11,336.26$ & & $12,112.51$ & & $12,888.76$ & & $13,665.01$ & & $14,441.26$ \\
\hline Quarterly interest ${ }^{4}(0.46 \%)$ & 9 months & 469.32 & & 501.46 & & 533.59 & & 565.73 & & 597.87 \\
\hline TOTAL GENERAL (ha-1) & & $11,805.58$ & & $12,613.97$ & & $13,422.36$ & & $14,230.74$ & & $15,039.13$ \\
\hline
\end{tabular}

${ }^{1}$ Cost: Seedling quantity multiplied by the price paid to the producer, which was $\mathrm{R} \$ 2.00 \mathrm{~kg}^{-1} .{ }^{2}$ Cost of broiler manure, $\mathrm{R} \$ 90.00$ per ton. ${ }^{3}$ Cost: land leasing, R\$ 150.00 per hectare per month, for 9 months. ${ }^{4}$ FCO Interest/Small Farmer-Source Banco Brasil. Heid et al. (2015). ${ }^{5}$ MFRural 2015, available at: http://www.mfrural.com.br.

The inputs accounted for $26.02 \%(\mathrm{R} \$ 3,072.62)$ of the costs of cultivation in soil without broiler manure addition, and $32.40 \%(\mathrm{R} \$ 4,872.62)$ of the costs of cultivation in soil covered with $20.00 \mathrm{Mg}$ $\mathrm{ha}^{-1}$ of broiler manure at 250 DAP. This difference in expenditure was related to the broiler manure doses applied per hectare.

Machinery costs included the costs of irrigation pump rental and tractor for land preparation, with a fixed amount of $R \$ 1,280.00$ in variable costs, which varied by $2.33 \%$ between treatments without and with $20 \mathrm{Mg} \mathrm{ha}^{-1}$ of broiler manure.
The fixed costs ( $\mathrm{R} \$ 1,725.00)$ accounted for $14.61 \%$ of the total cost of cultivation in soil without broiler manure addition, and $11.47 \%$ of the cost of cultivation in soil covered with $20 \mathrm{Mg} \mathrm{ha}^{-1}$ of broiler manure.

Other costs (contingency, administration, and interest) accounted for $14.59 \%$ of the total cost of cultivation in soil without broiler manure addition, and $15.00 \%$ of the total cost of cultivation in soil covered with $20 \mathrm{Mg} \mathrm{ha}^{-1}$ of broiler manure.

The different values calculated for production costs, in relation to the analyzed treatments, demonstrated the need to develop the best mode 
of arracacia cultivation, based on the use of broiler manure to cover soil, considering total cost reduction.

Considering the average productivities of the marketable roots obtained in each treatment (Figure 6) and estimates of gross income, production costs, and net income (Table 3), the cultivation of Amarela de Carandaí arracacia using broiler manure at $15 \mathrm{Mg}$ $\mathrm{ha}^{-1}$, either with sawdust or rice hulls, harvested at 250 DAP, was observed to generate higher values of marketable root production, which were $5.77 \mathrm{Mg}$ $\mathrm{ha}^{-1}$ and $5.20 \mathrm{Mg} \mathrm{ha}^{-1}$ for plants cultivated in soil covered with broiler manure containing sawdust and rice hulls, respectively, with a production cost of $\mathrm{R} \$ 14,430.74$.

The highest gross $(\mathrm{R} \$ 34,620.00)$ and net $(\mathrm{R} \$$ $20,389.26)$ incomes, with a production cost of $\mathrm{R} \$$ $14,230.74$, were obtained in the treatment where we used broiler manure containing sawdust $(15 \mathrm{Mg}$ $\mathrm{ha}^{-1}$ ), which exceeded that obtained with treatment with rice hull-based broiler manure $\left(5 \mathrm{Mg} \mathrm{ha}^{-1}\right)$ by $2.44 \mathrm{Mg} \mathrm{ha}^{-1}$ of marketable roots, with a production cost of $\mathrm{R} \$ 1,616.77$, gross income of $\mathrm{R} \$ 14,640.00$, and net income of $\mathrm{R} \$ 13,023.23$, which provided the lowest net income.

The economic results prove the need to economically study the applications of agricultural techniques and certain indices of the economic results.

\section{Conclusions}

The highest productivity of marketable arracacia roots was obtained from plants cultivated in soil covered with $16 \mathrm{tha}^{-1}$ of broiler manure.

The highest net income was obtained with arracacia grown in soil covered with $15 \mathrm{t} \mathrm{ha}^{-1}$ of broiler manure.

Table 3. Productivity of marketable roots of Amarela de Carandaí arracacia, and gross income, production cost, and net income as functions of plant cultivation in soil covered with different doses of broiler manure. UFGD, Dourados, MS, 2014-2015.

\begin{tabular}{ccccc} 
Broiler manure $\left(\mathrm{t} \mathrm{ha}^{-1}\right)$ & Commercial Production & Gross Income & Production Cost $\mathrm{t}^{2}$ & Net Income \\
\hline Sawdust & $\left(\mathrm{t} \mathrm{ha}^{-1}\right)$ & $\left({\left.\mathrm{R} \$ \mathrm{ha}^{-1}\right)}^{-1}\right.$ & $\left(\mathrm{R} \mathrm{ha}^{-1}\right)$ & $\left(\mathrm{R} \mathrm{ha}^{-1}\right)$ \\
Without & 3.38 & $20,280.00$ & $11,805.58$ & $8,474.42$ \\
5 & 4.84 & $29,040.00$ & $12,613.97$ & $16,426.03$ \\
10 & 5.32 & $31,920.00$ & $13,422.36$ & $18,497.64$ \\
15 & 5.77 & $34,620.00$ & $14,230.74$ & $20,389.26$ \\
20 & 5.70 & $34,200.00$ & $15,039.13$ & $19,160.87$ \\
\hline Rice hulls & & & & \\
Without & 3.30 & $19,800.00$ & $11,805.58$ & $7,994.42$ \\
5 & 3.33 & $19,980.00$ & $12,613.97$ & $7,366.03$ \\
10 & 3.66 & $21,960.00$ & $13,422.36$ & $8,537.64$ \\
15 & 5.20 & $31,200.00$ & $14,230.74$ & $16,969.26$ \\
20 & 4.33 & $25,980.00$ & $15,039.13$ & $10,940.87$ \\
\hline
\end{tabular}

${ }^{1} \mathrm{R} \$ 6.00 \mathrm{~kg}^{-1}$. Price paid for a kilogram of arracacia at the central street market in Dourados, MS. ${ }^{2}$ Cost of producing Amarela de Carandaí arracacia in one hectare of land. 


\section{Literature Cited}

Alvares, C.A.; J.L. Stape; P.C. Sentelhas; J.L.M. Gonçalves y G. Sparovek.

2013. Köppen's climate classification map for Brazil. Meteorologische Zeitschrift, Germany, 22(6): 711-728.

Ávila, V.S., A. Kunz, C. Bellaver, D.P. Paiva, F.R. Jaenisch, H. Mazzuco, I.M. Trevisol, J.C.P. Palhares, P.G. Abreu, y P.S. Rosa.

2007. Boas práticas de produção de frangos de corte. Concórdia: Embrapa Suínos e Aves. Circular Técnica, 51: $28 \mathrm{p}$.

Carmo, E.L. y M. Leonel.

2012. Composição físico-química e cor de clones de mandioquinha-salsa. Revista Energia na Agricultura, 27(1): $62-81$.

Chaves, C. 2016. Marketing of mandioquinha-salsa in MS. CEASA - MS, Campo Grande, Brazil.

Chen, B., E. Liu, Q. Tian, C. Yan y Y. Zhang.

2014. Soil nitrogen dynamics and crop residues. A review. Agronomy for Sustainable Developmente, 34(2): 429-442.

Filgueira, F.A.R.

2008. Novo manual de olericultura: agrotecnologia moderna na produção e comercialização de hortaliças. $3^{\mathrm{a}}$ ed. Editora UFV, Viçosa, Brasil. 412 p.

Graciano, J.D., N.A. Heredia Zárate, M.C. Vieira, Y.B.C. Jardim

Rosa, M.A.N. Sediyama y E.T. Rodrigues.

2006. Efeito da cobertura do solo com cama de frango semidecomposta sobre dois clones de mandioquinha-salsa. Acta Scientiarum Agronomy, 28(3): 365-371.

Heid, D.M., Zárate, N.A.H., Torales, E.P., Luqui, L.L., Moreno,

L.B., Carnevali, T.O., Vieira, M.C., Amarila, I.R.

2019. Seedling size and broiler litter composition affect Peruvian carrot productivity and profitability. Revista Brasileira de Ciências Agrárias, 14(2): 1-8.

Heid, D.M., N.A. Heredia Zárate, M.C. Vieira, E.P. Torales, T.O. Carnevali y B.G. Marafiga.

2015. Produtividade agroeconômica de mandioquinha-salsa em resposta à adição de cama-de-frango no solo. Semina: Ciências Agrárias, 36(3): 1835-1850.

Heredia Zárate, N.A., M.C. Vieira, J.D. Graciano, P.G. Figueiredo, N.B. Blans y B.M. Curioni.

2009. Produtividade de mandioquinha-salsa sob diferentes densidades de plantio e tamanho de mudas. Ciência e Agrotecnologia, 33(1): 139-143.

Hoshino, R.T., G.A.C. Alves, T.R. Melo, R.R. Barzan, G.A.F. Fregonezi y R.T. Faria.

2016. Adubação mineral e orgânica no desenvolvimento de orquídea Cattlianthe 'Chocolate drop'. Horticultura Brasileira, 34(4): 475-482.

Kiehl, E.J.

2010. Novos fertilizantes orgânicos. Degaspari, Piracicaba - Brasil, 248 p.

Madeira, N.R. y R.J. Souza.

2004. Mandioquinha-salsa: alternativa para o pequeno produtor. UFLA, Lavras, 71 p.
Mangiori, V.R.L. y J.T. Filho.

2015. Disposição de resíduos sólidos no solo: efeitos nos atributos físicos, químicos e na matéria orgânica. Semina: Ciências Agrárias, 36(2): 747-764.

Melo, A.S, B.C. Costa, M.E.B. Brito, A.O.A. Aguiar Netto y

P.R.A. Viégas.

2009. Custo e rentabilidade na produção de batata-doce nos perímetros irrigados de Itabaiana, Sergipe. Pesquisa Agropecuária Tropical, 39(2): 119-123.

Nunes, E.E, E.V.B. Vilas Boas, R.H. Piccoli, A.L.R.P. Xisto y B.M. Vilas Boas.

2010. Efeito de diferentes temperaturas na qualidade de mandioquinha- salsa minimamente processada. Horticultura Brasileira, 28(3): 311-315.

Oliveira, F.A., A.F. Oliveira Filho, J.F. Medeiros, A.B. Almeida

Júnior y P.C.F. Linhares.

2009. Desenvolvimento inicial da mamoeira sob diferentes fontes e doses de matéria orgânica. Revista Caatinga, 22(1): 206-211.

Paula Júnior, S.E.M.

2014. Avaliação das alternativas de disposição final do resíduo da produção de frango de corte: cama de frango. Monografia - Engenharia Ambiental. Universidade Federal do Rio de Janeiro, Rio de Janeiro, Brazil.

Pádua, J.G.

2010. Produção de batata e mandioquinha-salsa visando o processamento industrial. Revista Raízes e Amidos Tropicais, 6(1): 147-161.

Santos, H.G.; Jacomine, P.K.T.; Anjos, L.H.C.; Oliveira, V.A.; Lumbreras, J.F.; Coelho, M.R.; Almeida, J.A.; Araújo Filho, J.C.; Oliveira, J.B.; Cunha, T.J.B.

2018. Sistema brasileiro de classificação de solos. $5^{\text {a }}$ Edição revista e ampliada. Brasília: Embrapa Solos. 590 p.

Sediyama, M.A.N., R.S. Freitas, P.C. Pereira, T. Sediyama, M.H.T. Mascarenhas y F.A. Ferreira.

2008. Avaliação de herbicidas no controle de plantas daninhas em mandioquinha-salsa. Bragantia, 67(4): 921-926.

Torales, E.P., N.A. Heredia Zárate, M.C. Vieira, R.P. Gassi, N.A. Salles y J.V.C. Pinto.

2014. Influência da cama de frango e de espaçamentos entre plantas na produtividade agroeconômica de mandioquinhasalsa. Revista Ceres, 61(2): 162-171.

Torales, E.P., N.A. Heredia Zárate, S.C.H. Vieira, M.M. Resende, C.M.S. Sangalli y R.P. Gassi.

2010. Doses de cama-de-frango e densidade de plantio na produção de mandioquinha-salsa Amarela de Carandaí. Semina: Ciências Agrárias, 31(1): 1165-1176.

Tulsian, M. Profitability Analysis (A comparative study of SAIL \& TATA Steel).

2014. IOSR Journal of Economics and Finance, 3(2): 19-22.

Valadão, F.C.A., K.D.B. Maas, O.L.S. Weber, D.D. Valadão Júnior y T.J. Silva.

2011. Variação nos atributos do solo em sistemas de manejo com adição de cama de frango. Revista Brasileira de Ciência do Solo, 35(6): 2073-2082. 
